\title{
"Interdisciplinary" Legal Studies and the Emergence of New Academic Teachings: A Research Project on Law Courses in 19th-20th Century Italy
}

\author{
Estudios legales "interdisciplinares" y la aparición de nue- \\ vas enseñanzas académicas: un proyecto de investigación \\ sobre los cursos de Derecho en Italia en los siglos XIX y XX.
}

\author{
Annamaria Monti \\ Bocconi University \\ DOI: http://dx.doi.org/10.20318/cian.2016.3145 \\ Recibido: $\quad$ 12/04/2016 \\ Aceptado: $\quad 17 / 05 / 2016$
}

\begin{abstract}
The profound change in thinking about the law experienced by European jurists at the turning of the 20th century is well known: they renewed their methods, also through the influence of German legal thought and the impact of new social sciences. Focusing on the Italian experience, the research intends to investigate how this innovative change was linked to the teaching of law. Most certainly, new courses were introduced. Concerning the contents of the teachings, another point to investigate are the connections with the legal thought circulating at a transnational level in those times.

Keywords: legal education; legal doctrine; Italian universities (19th-20th centuries); teaching methods; legal studies.
\end{abstract}

Resumen: El cambio profundo en la manera en la que se pensaba el derecho que experimentaron los juristas europeos a principios del siglo XX es bien conocido: renovaron sus métodos, en parte bajo la influencia del pensamiento jurídico alemán y el impacto de nuevas ciencias sociales. Nuestra investigación, que se centra en la experiencia italiana busca determinar el modo en que aquella innovación estuvo vinculada a la enseñanza del derecho. Seguramente se introdujeron nuevas asignaturas. En cuanto al contenido de aquella enseñanza, otro aspecto a investigar consiste en su conexión con el pensamiento jurídico que circulaba en aquel entonces a nivel transnacional.

Palabras clave: enseñanza jurídica; doctrina jurídica; universidades italianas (siglo XIX y XX); métodos de enseñanza; estudios jurídicos.

* Department of Legal Studies "Angelo Sraffa”, Bocconi University, Milan, Italy, http://faculty.unibocconi.eu/annamariamonti, annamaria.monti@unibocconi.it 


\section{A research project on legal education in $19^{\text {th }}-20^{\text {th }}$ century Italy}

From the end of the $19^{\text {th }}$ century to the first half of the $20^{\text {th }}$ century people and ideas - as well as capital - circulated intensively at a transnational level. Referring to legal thought, the cultural exchanges of the time that happened among jurists and in particular among law professors represent a challenging field of study.

The profound change in thinking about the law experienced by jurists in those times is well known: jurists renewed their methods, also through the influence of German legal thought, which itself was going through a period of heated critical debate. ${ }^{1}$ It occurred in Italy, as well as in other countries, as historiography has already investigated and clearly demonstrated. ${ }^{2}$ Nowadays, literature on nineteenth century legal thought and methodology is rich.

The research question I am interested in is precisely how this innovative change was connected to the teaching of law, a crucial issue to verify being if and how law courses reflected the renewal and participated in it. In Italy, for example, historiography pointed out how law professors seized the opportunity of the inaugural lectures (prolusioni) of the academic year to discuss methodological questions, ${ }^{3}$ but a comprehensive analysis of the contents of the courses is still lacking. ${ }^{4}$

\footnotetext{
${ }^{1}$ In English translation, Franz Wieacker, $A$ history of private law in Europe: with particular reference to Germany, translated by Tony Weir, foreword by Reinhard Zimmermann (Oxford: Clarendon Press, 1998); Michael Stolleis, A history of public law in Germany, 1914-1945, translated by Thomas Dunlap (Oxford - New York: Oxford University Press, 2004). Among others, Olivier Jouanjan, Une histoire de la pensée juridique en Allemagne (1800-1918). Idéalisme et conceptualisme chez les juristes allemands du XIXe siècle (Paris: PUF, 2005); Methodik des Zivilrechts: von Savigny bis Teubner, eds. Joachim Rückert, Ralf Seinecke (Baden-Baden: Nomos Verlagsgesellschaft, 2012); Savigny International?, eds. Joachim Rückert and Thomas Duve (Frankfurt am Main: Vittorio Klostermann, 2015). See also, Jean-Louis Halpérin, Histoire de l'état des juristes. Allemagne, XIXe-XXe siècles (Paris: Classiques Garnier, 2015).

${ }^{2}$ Refer to Paolo Grossi, Scienza giuridica italiana. Un profilo storico (Milano: Giuffrè, 2002).

${ }^{3}$ Paolo Grossi, "Le 'prolusioni' dei civilisti e la loro valenza progettuale nella storia della cultura giuridica italiana," Quaderni fiorentini 41 (2012): 399-426; Giovanni Cazzetta, "Prolusioni, prelazioni, discorsi. L'identità nazionale nella retorica dei giuristi," in Retoriche dei giuristi e costruzione dell'identità nazionale, ed. Giovanni Cazzetta (Bologna: Il Mulino, 2013), 11-29; Mario Caravale, "Introduzione," in La Facoltà giuridica romana in età liberale. Prolusioni e discorsi inaugurali, eds. Mario Caravale and Francesca L. Sigismondi (Napoli: Jovene, 2014). See also Paolo Alvazzi del Frate, Dario Di Cecca, "Droit et méthodologie. Les prolusioni accademiche en Italia au XIXe siècle," Revue d'histoire des Facultés de droit et de la culture juridique 31 (2011): 117-138.

${ }^{4}$ See Giulio Cianferotti, "Germanesimo e università in Italia alla fine dell'800. Il caso di Camerino," Studi senesi (1988): 327-347; Giulio Cianferotti, "L'università di Siena e la 'ver-
} 
Indeed, at the turn of the $20^{\text {th }}$ century, a rethinking of law-teaching methods and their contents across Europe was stimulated by a number of factors, namely: the economic and industrial development of the late nineteenth century; the appearance of 'social sciences' such as sociology; the emergence of new fields of study, such as statistics and economics; and, of course, the influence of German legal doctrine and the impact of the new German codification of 1900 , the $B G B$.

However, the diffusion of German legal doctrine did not mean the monopolisation of legal methods and thinking. Connections and reciprocal influences among jurists facilitated exchanges, as well as "contamination" with other legal teachings. The above mentioned emerging social sciences contributed significantly to the debate, both at a national and international level. ${ }^{5}$

For example, at the end of the $19^{\text {th }}$ century, not only Roman law, but also more ancient laws were studied and often in a comparative perspective.

tenza Scialoja'. Concettualismo giuridico, giurisprudenza pratica e insegnamento del diritto in Italia alla fine dell'Ottocento," Studi Senesi Supplemento II (1988): 725-750; Giulio Cianferotti, "La prolusione di Orlando. Il paradigma pandettistico, i nuovi giuristi universitari e lo Stato liberale," Rivista trimestrale di diritto pubblico 4 (1989): 995-1023. Among other recent single studies, Luciano Musselli, "La Facoltà di Giurisprudenza di Pavia nel primo secolo dell'Italia unita (1860-1960)," Annali di Storia delle Università italiane 7 (2003), http:// www.cisui.unibo.it/frame_annali.htm; Laura Passero, "La Facoltà giuridica pisana negli anni Ottanta dell'Ottocento," Studi Senesi (2007): 322-359; La Facoltà di Giurisprudenza della Regia Università degli Studi di Messina (1908-1946), ed. Giacomo Pace Gravina (Messina: GBM, 2009); Antonello Mattone, "Gli studi giuridici e l'insegnamento del diritto (XVII-XX secolo)," in Storia dell'Università di Sassari, ed. Antonello Mattone (Nuoro: Ilisso, 2010), I, 209 ff.; Enrico Spagnesi, "L'insegnamento del diritto 'al modo pisano' (1861-1945)," Annali di Storia delle Università italiane 14 (2010), http://www.cisui.unibo.it/frame_annali.htm; Paolo Nardi, "Lodovico Zdekauer a Macerata tra archivi e insegnamento universitario," Annali di Storia delle Università italiane 14 (2010), http://www.cisui.unibo.it/frame_annali.htm; Maria Gigliola di Renzo Villata, "Per una storia del diritto (italiano). Antonio Pertile e la prima cattedra della materia," Quaderni per la storia dell'Università di Padova 45 (2012): 63-103; Antonia Fiori, "Gli insegnamenti storico-giuridici alla Sapienza negli ultimi decenni del XIX secolo," Historia et ius 4 (2013), paper 10; Giordano Ferri, "Studi di diritto processuale civile nella Facoltà giuridica romana tra Ottocento e Novecento," Historia et ius 4 (2013), paper 9; Mario Caravale, "«Come si assicurano i diritti degli individui e delle nazioni? Colla libertà costituzionale» I primi corsi di diritto costituzionale a Roma dopo l’Unità," in Retoriche dei giuristi, 203-230.

${ }^{5}$ Carlos Petit, "«Qualcosa che somiglia all'ammirazione». Ecos de la Civilística italiana en España," in Giuseppe Pisanelli. Scienza del processo cultura delle leggi e avvocatura tra periferia e nazione, ed. Cristina Vano (Napoli: Jovene, 2005), 397-444; Ferdinando Mazzarella, "Dialoghi a distanza in tema di socialità e storicità del diritto. Italia, Francia e Germania tra fine Ottocento e primo Novecento," Quaderni fiorentini 44/1 (2015): 381-424; Le "moment 1900". Critique sociale et critique sociologique du droit en Europe et aux Etats-Unis, eds. Olivier Jouanjan and Elisabeth Zoller (Paris: Editions Panthéon Assas, 2015). 
Ideas and laws studied from the colonial world contributed to the development of this kind of study. One could think of the very successful masterpiece written in 1861 by the British jurist Henry Sumner Maine, Ancient Law, a bestseller in continental Europe. One might also think of the success with jurists of the work on prehistoric matriarchy, Mother Right (Mutterrecht), written by the Swiss jurist and anthropologist Bachofen, also published in $1861{ }^{6}$

Ethnography and anthropology were not the only new subjects; on the contrary, they were but two of the significant topics of that period, as well as sociology, in its different interpretations. Initially, this kind of study was experimented by scholars who were interested in these new fields of research. ${ }^{7}$ Very soon indeed, these same studies and, more generally, the so called 'social sciences' had an impact on legal studies and received great attention from a number of law professors, seeking new legal methods of interpretation. ${ }^{8}$

Ethnography, for example, was an initial way of comparison which fascinated jurists, who started looking back to the past: a very well known Italian professor of Roman law, Pietro Bonfante, who had the chair of Roman law at Pavia University and then at Roma Sapienza University and also taught history of commerce at Bocconi University, together with his colleague Longo, translated from the original German language into Italian Albert Hermann Post's work on legal anthropology and ethnography. ${ }^{9}$ Bonfante contributed to the success of Post with Italian scholars. ${ }^{10}$

${ }^{6}$ Luigi Capogrossi Colognesi, Modelli di stato e di famiglia nella storiografia dell'800 (Roma: La Sapienza, 1994) 43 ff., 141 ff.; Roy Garré, "Prospettive della comparazione giuridica nel pensiero e nell'opera di J.J. Bachofen (1815-1887)," in La comparazione giuridica tra Ottocento e Novecento. In memoria di Mario Rotondi (Milano: Istituto Lombardo di Scienze e Lettere, 2001), 99-120; David M. Rabban, Law's History. American legal Thought and the Transatlantic Turn to History (New York, Cambridge University Press, 2013), $115 \mathrm{ff}$.

${ }^{7}$ Sandra Puccini, "A casa e fuori: antropologi, etnologi, viaggiatori," in Scienza e cultura dell'Italia unita, Storia d'Italia, Annali, 26, eds. Francesco Cassata and Claudio Pogliano (Torino: Einaudi, 2011), 547-573.

${ }^{8}$ Paolo Grossi, « La scienza del diritto privato ». Una rivista-progetto nella Firenze di fine secolo. 1893-1896 (Milano: Giuffrè, 1988); Ferdinando Mazzarella, "Darwinismo, storicismo, socialità. «La nuova tendenza» di Giuseppe Vadalà-Papale," Quaderni fiorentini 41 (2012): 583-626.

${ }^{9}$ Alberto Ermanno Post, Giurisprudenza etnologica, traduzione con prefazione e postille dei proff. Pietro Bonfante e Carlo Longo dell'Università di Pavia, vol. I (Milano: Società editrice libraria, 1906).

${ }^{10}$ Alba Negri, Il giurista dell'area romanista di fronte all'etnologia giuridica (Milano: Giuffrè, 1983). See also Riccardo Orestano, Introduzione allo studio del diritto romano (Bologna: Il Mulino, 1987), 301-304; Aldo Schiavone, “Un'identità perduta: la parabola del diritto romano 
The research project on legal education in $19^{\text {th }}-20^{\text {th }}$ century Italy (and the related idea of a new database) aims precisely at studying the Italian legal education system at the turn of the $20^{\text {th }}$ century from the point of view of the teaching, also to verify the influence of social sciences and the connections with the legal thought circulating in those times.

After a comprehensive survey of topics and methods of law courses taught in Italian Universities back then, the analysis will focus specifically on the so called 'free' courses which renewed the general program of law studies. The first step will be to "map" these teachings and special care will be devoted to collecting and analysing textbooks and students' notes. ${ }^{11}$

The easiest way would be to start from the teachers, choosing a prosopographical approach, also bearing in mind that one of the outputs of the project should be the creation of a new database, following the example of databases like Siprojuris, devoted to French law professors, ${ }^{12}$ or the Diccionario de catédraticos españoles de derecho, devoted to Spanish law professors. ${ }^{13}$

Concerning Italian law professors, in fact, we have no such database yet. To my knowledge there is only the website edited by Dario Mantovani and Elisa Signori collecting information on Pavia University's professors

in Italia," in Stato e cultura giuridica in Italia dall'Unità alla Repubblica, ed. Aldo Schiavone (Roma - Bari: Laterza, 1990), 287-293.

${ }^{11}$ In Spain, this topic has already been investigated: Manuel Martínez Neira, El estudio del derecho libros de texto y planes de estudio en la universidad contemporánea (Madrid: Instituto Antonio de Nebrija de estudios sobre la Universidad, 2001); Manuel Martínez Neira, "Los libros útiles o la utilidad de los libros. Manuales de derecho entre 1841 y 1845," in Manuales y textos de enseñanza en la Universidad liberal, ed. Manuel Ángel Bermejo Castrillo (Madrid: Instituto Antonio de Nebrija de estudios sobre la Universidad, 2004), 581-592. Recent research focused on it also in France: Guillaume Richard, "La Faculté de Paris et l'aide aux étudiants sous la Troisième République," in Paris, capital juridique (1804-1950). Etude de socio-histoire sur la Faculté de droit de Paris, ed. Jean-Louis Halpérin (Paris: Editions Rue d'Ulm, 2011), 211-214; Frédéric Audren, "Conclusion. Les juristes en travailleurs manuels," in Histoire des manuels de droit. Une histoire de la littérature juridique comme forme du discours universitaire, ed. Anne-Sophie Chambost (Paris: LGDJ, 2014), 337-345; Guillaume Richard, Enseigner le droit public à Paris sous la Troisième République (Paris: Dalloz, 2015).

${ }^{12}$ http://siprojuris.symogih.org/ Accessed April 8, 2016. See Frédéric Audren, Jean-Louis Halpérin, La culture juridique française. Entre mythes et réalités (Paris: CNRS Editions, 2013).

${ }_{13} \mathrm{http}: / /$ portal.uc3m.es/portal/page/portal/instituto_figuerola/programas/phu/diccionariodecatedraticos Accessed April 8, 2016. See Sebastián Martín, "De la enseñanza a la ciencia del derecho: biografía colectiva de juristas españoles (1857-1943)," Cuadernos del Instituto Antonio de Nebrija 12/1 (2009): 33-51. Refer also to Carlos Petit, "De la historia a la memoria. A propósito de una reciente obra de historia universitaria," Cuadernos del Instituto Antonio de Nebrija 8 (2005): 237-279. 
from the yearly university gazettes (Annuari) for the period $1859-1961 .{ }^{14}$ It is indeed a precious tool for researchers, but most certainly not exhaustive.

Of course, we can count on recent and valuable collective print works and dictionaries like the Dizionario biografico dei giuristi italiani (XII-XX secolo), edited by Italo Birocchi, Ennio Cortese, Antonello Mattone and Marco Nicola Miletti, (Bologna: Il Mulino, 2013) or Il contributo italiano alla storia del pensiero. Diritto, Enciclopedia italiana di scienze lettere ed arti, Ottava appendice, edited by Paolo Cappellini, Pietro Costa, Maurizio Fioravanti and Bernardo Sordi (Roma: Istituto della Enciclopedia Italiana, 2012), which contain some relevant information on 19th and 20th century jurists. Notwithstanding the above, to conduct this research one must search the archives of universities and central archives in Rome to collect the relevant data concerning programs, teachers and teachings.

Furthermore, we have a number of significant studies dealing with Italian Universities after Unification - and in particular, I am thinking of the fundamental contributions by Ilaria Porciani and Mauro Moretti. ${ }^{15}$ Nowadays, literature on universities as well as on the university system in those times is very rich and this represents a solid base for further research and specifically for the research project on law courses at the turning of the $20^{\text {th }}$ century.

Thanks to these studies, we are aware that after Unification universities were regarded as fundamental institutions, together with bureaucracy and the army, to build the new unified State and to prepare its ruling class (which, by the way, was largely made up of lawyers). That was why universities received special attention from the government and also played a political role.

In synthesis, through the initial reform of 1859 (legge Casati) and other following regulations - which seemed to be inspired by the French Napoleonic system, rather than by the highly appreciated German example ${ }^{16}$ - tenured faculty recruiting was centralized through a system of national competitions and university programs and curricula had to be approved by the minister of public education. Schools held by private teachers in the field of law which had been quite common, especially in Naples and in southern

${ }^{14}$ http://prosopografia.unipv.it/ Accessed April 8, 2016.

${ }^{15}$ Among many other contributions, Ilaria Porciani and Mauro Moretti, "La creazione del sistema universitario nella nuova Italia," in Storia delle Università in Italia, ed. Gian Paolo Brizzi, Piero Del Negro and Andrea Romano (Messina: Sicania, 2007), I, 323-379. See also L'università tra Otto e Novecento: i modelli europei e il caso italiano, ed. Ilaria Porciani (Napoli: Jovene, 1994).

${ }^{16}$ For a synthesis, Stefan Fisch, Geschichte der europäischen Universität. Von Bologna nach Bologna (München: C.H. Beck, 2015). 
Italy, gradually disappeared so that legal education was only available at universities.

In fact, during Restoration and before Unification universities in Italy had developed in different ways in the different States into which the country had been previously divided. Each State had its peculiarities specifically concerning legal education, and for the pre-unification period scholars have already searched teaching methods and sometimes also textbooks. ${ }^{17}$ I can quote Aldo Mazzacane and Cristina Vano's studies ${ }^{18}$ as well as a fundamental collective volume on Emanuele Gianturco, a Neapolitan $19^{\text {th }}$ century jurist, published in $1987,{ }^{19}$ and of course the essays on case methods by Ferdinando Treggiari. ${ }^{20}$

Other recent works focused on the question of the independence of the universities from the State and their financial autonomy. ${ }^{21}$ The reform of 1859 was not satisfactory, and as a result, when industrial revolution arrived in Italy, determining changes in society and economy, an important debate on the university system started. It happened during the 1880s. And in this debate other European examples were taken into great consideration, especially the French and the German ones. ${ }^{22}$

Apart from these studies, however, our knowledge of law courses after Unification is still lacking and it clearly deserves scholars' attention.

\section{Chairs, teachings and the emergence of new academic disciplines.}

At the turn of the $20^{\text {th }}$ century in many Italian Universities the quality of teaching had increased: professors were selected through public exams and

\footnotetext{
${ }^{17}$ For bibliographical reference, please refer to Annamaria Monti, "Tradizione e rinnovamento nella didattica giuridica: prime riflessioni per un'indagine sull'Italia liberale," Rivista di storia del diritto italiano 87 (2014): 287-312.

${ }^{18}$ I giuristi e la crisi dello Stato liberale in Italia fra Otto e Novecento, ed Aldo Mazzacane (Napoli: Liguori Editore, 1986); Università e professioni giuridiche in Europa nell'età liberale, ed Aldo Mazzacane, Cristina Vano (Napoli: Jovene, 1994).

${ }^{19}$ L'esperienza giuridica di Emanuele Gianturco, ed. Aldo Mazzacane (Napoli: Liguori Editore, 1987).

${ }^{20}$ Ferdinando Treggiari, "Itinerari della casistica. La crestomazia di Emanuele Gianturco fra modelli illustri e nuove istanze," in Emanuele Gianturco, Crestomazia di casi giuridici in uso accademico (rist. an. Bologna: Forni, 1989), V-XLVI.

${ }^{21}$ Floriana Colao, La libertà di insegnamento e l'autonomia nell'Università liberale. Norme e progetti per l'istruzione superiore in Italia (Milano: Giuffrè, 1995).

${ }^{22}$ Robert D. Anderson, European Universities from Enlightenment to 1914 (Oxford: Oxford University Press, 2004), 151-190.
} 
they were evaluated according to their publications: tenured professors were selected nationally, while a number of other teachers were selected locally. ${ }^{23}$ Moreover, law professors were in most cases well known lawyers and, in many cases, also politicians. ${ }^{24}$

In addition, from the point of view of the organisation of the classes, in late $19^{\text {th }}$ and early $20^{\text {th }}$ century Italian universities it was quite common for a law professor to teach different courses.

For example, Roman law and private law, which were the main teachings, were often taught by the same professors. This was because in Italy Roman law was studied according to Savigny's method and it was considered part of private civil law. Sometimes, also commercial law and civil procedure were taught by the same person. Even if specialisation had increased, this could be seen as the remains of the previous tradition of having a few "generalist" professors who could teach different subjects.

And all these groups of professors took advantage of the so called "free teachings" to teach new subjects, namely comparative legislation or comparative law; labour law; industrial law; philosophy of law: usually, the free courses were held by the so called private lecturers (liberi docenti), an Italian version of the German Privatdozenten, but tenured faculty could also teach them.

This was a very complex system of teachers and teachings the study of which seems worthwhile.

As an example, one could consider the law program of Turin University from the beginning of the $20^{\text {th }}$ century (in those times Turin was one of the leading law faculties in Italy): the number of "free", not ordinary teachings was impressive. As mentioned above, not only the private lecturers taught them, but very often the full professors asked the faculty to teach at least one "free" class, where they could experiment with new subjects and topics. Moreover, in the same Turin University important teachings of economics were developed (Laboratorio Cognetti de Martiis) and Luigi Einaudi (who went on to become president of the Italian Republic) taught financial law (scienza delle finanze) there. ${ }^{25}$

${ }^{23}$ Tina Tomasi, Luciana Bellatalla, L'Università italiana nell'Italia liberale (1861-1923) (Napoli: Liguori Editore, 1988); Massimo Moretti, Ilaria Porciani, "Il reclutamento accademico in Italia. Uno sguardo retrospettivo," Annali di storia delle università italiane (1997): 11-39.

${ }^{24}$ Aldo Mazzacane, "Secolo dell'università - secolo delle professioni: le ragioni di un incontro," in Università e professioni giuridiche, 9.

25 "La Scuola di Torino. Da Cognetti de Martiis a Einaudi," Il pensiero economico italiano XII/2 (2004); Roberto Marchionatti, et al., "« Quando l'economia italiana non era seconda a nessuno ». Luigi Einaudi e la Scuola di economia di Torino," in Luigi Einaudi nella cultura, nella 
One specific and very interesting case was comparative law. In fact, among the most significant changes that occurred in legal education at the turn of the $20^{\text {th }}$ century, and specifically in Italy, were new teachings of "modern" comparative law in Law Schools. Furthermore, comparative law and legal education seem to me to have always been closely connected: this connection has been evident since modern comparative law studies started, between the $19^{\text {th }}$ and the $20^{\text {th }}$ century. ${ }^{26}$

Concerning the comparative law teachings held at Turin Law School, Emilio Brusa, a criminal law professor, taught comparative criminal legislations; Giovanni Pacchioni, a Roman and private law professor, held the course of comparative legislations; Mario Sarfatti taught English and comparative law. ${ }^{27}$

Indeed, comparative law was considered a very interesting field of study as well as a very important subject in the preparation of prospective lawyers. And not only for lawyers, as proven by the teachings of law which started in 1902 in Milan, at Bocconi University, which were aimed not at law students, but at students of this newly founded Economic and Business School. ${ }^{28}$ In fact, the studies in law were of fundamental importance to the economic education provided by Bocconi at the time,$^{29}$ especially private law, public law and commercial law. ${ }^{30}$ Therefore, law classes were held by well known law professors who, through their teachings, often explored new fields.

In particular, the sociologist and political science scholar Gaetano Mosca, professor of public law at Turin Law School, at Bocconi taught constitutional law in a comparative perspective and the already mentioned Giovanni Pacchioni taught comparative commercial law.

società e nella politica del Novecento, eds. Roberto Marchionatti, Paolo Soddu (Firenze: L. S. Olschki, 2010), 57-99.

${ }^{26}$ Carlos Petit, "Lambert en la Tour Eiffel, o el derecho comparado de la Belle Epoque," in La comparazione giuridica tra Otto e Novecento, 53-98.

${ }^{27}$ As an example, see Archivio storico dell'Università di Torino, Verbali della Facoltà di giurisprudenza dal 27 ottobre 1902 al 30 marzo 1909, Adunanza del 19 marzo 1906 and Adunanza del 24 marzo 1906.

${ }^{28}$ Marco Cattini, et al., Storia di una libera università, I, L'Università Commerciale Luigi Bocconi dalle origini al 1914 (Milano: Giuffrè, 1992). Recently, Marzio Achille Romani, "I problemi e le riforme didattiche nella prima «università commerciale» italiana: la Bocconi (19021932)," Annali di Storia delle Università italiane 19 (2015): 125-135.

${ }^{29}$ Didier Musiedlak, Université privée et formation de la classe dirigeante: l'exemple de l'Université L. Bocconi de Milan (1902-1925) (Roma: Ecole française de Rome, 1990); Anderson, European Universities, 217-218.

${ }^{30}$ Tullio Bagiotti, Storia della Università Bocconi 1902-1952 (Milano: Università Bocconi, 1952). 
However, one could wonder what kind of comparative law these professors were teaching, at both universities, Turin and Milan Bocconi.

Mario Sarfatti, who is also considered to be one of the first Italian scholars devoted to studying and teaching private comparative law in law schools, started a pioneering exploration of English private law. At that time there wasn't really interest in Anglo American legal systems and a possible reason may simply have been a linguistic one. At the beginning of the $20^{\text {th }}$ century he became the lecturer of English and comparative law at Turin Law school where he taught until 1935. In those years he travelled and met other foreign scholars who were interested in the field: in particular, his ideas were aligned with Edouard Lambert's doctrines. ${ }^{31}$

So, in his teaching before World War I, Sarfatti mentioned the contemporary trend towards cosmopolitism as well as the recent industrial and commercial developments which contributed to dramatically increasing the economic exchanges among different countries. As a consequence many jurists felt the need to look at what happened outside their national legal systems, so that societies for comparative law grew in France, in England and in Germany. ${ }^{32}$ After the War, he spoke about the progress made by comparative law studies from the beginning of the nineteenth century to the first congress of Paris in 1900 (he specially mentioned the contribution of Saleilles) and onwards. ${ }^{33}$

Apart from the teachings of Sarfatti, one could think also of the teachings of the above mentioned Giovanni Pacchioni, professor of Roman law and civil law at the Universities of Innsbruck, Turin and Milan; professor of private international law at the Cairo University and professor of comparative commercial legislations at Bocconi University in Milan (1906-1909). ${ }^{34}$

Pacchioni wanted to renew the traditional methods of law interpretation: in particular, he refused the exegesis models and, instead, was more attracted by the German Pandekten, even if with some criticism: he felt the

${ }^{31}$ Annamaria Monti, "Alla scoperta del diritto anglo sassone: il contributo di Mario Sarfatti (1876 - 1962) alla comparazione giuridica," in Lavorando al cantiere del "Dizionario biografico dei giuristi italiani (XII-XX sec.)", ed. Maria Gigliola di Renzo Villata (Milano: Giuffrè, 2013), 589-623.

${ }^{32}$ Mario Sarfatti, "Sull'utilità dello studio del diritto privato inglese in Italia. Prolusione al corso libero di diritto civile comparato, R. Università di Torino 15 dicembre 1906," Il Filangieri 32 (1907).

${ }^{33}$ Mario Sarfatti, Introduzione allo studio del diritto comparato (Torino: Giappichelli, 1933).

${ }^{34}$ Annamaria Monti, "Enseigner le droit en Italie au début du XXe siècle: les cours de législation comparée de Giovanni Pacchioni (1867-1946)," in Aux confins du droit. Mélanges-Hommage amical à Xavier Martin (Paris: LGDJ, 2015), 305-314. 
need to change the legal methods and, as a very cultured and learned lawyer, he took advantage of his broad knowledge of law.

In his course, he chose to talk firstly about the history of continental civil law and of the history of modern codifications and then he looked at the Anglo American legal tradition, still from a historical perspective, mentioning Bentham's ideas. The second and most valuable part of his teaching was devoted to studying a specific problem always from a historical and comparative point of view. For example, in 1906 he chose to talk about bankruptcy. ${ }^{35}$

What seems worthwhile highlighting is that this Italian professor had developed his own comparative method, picking suggestions from the very rich literature he knew. His approach started from a historical analysis, but his focus, however, was always on the law in force in Italy and abroad. Both his legal culture and the fact that law professors in those times knew very well what their foreign colleagues wrote emerged in his classes. That was why Pacchioni's teaching of comparative legislations was also evidence of the circulation of legal thought.

Concerning Gaetano Mosca, he was an outstanding scholar of Piedmontese origin and born in Palermo, ${ }^{36}$ who elaborated an important doctrine on the elites and whose political thought was well known not only in Italy, but also abroad. ${ }^{37}$ At Bocconi, between 1902 and 1923, he held the course of constitutional and administrative law and later on, after World War One, a course of political science. ${ }^{38}$

${ }^{35}$ Corso speciale di legislazione comparata. Anno accademico 1906-1907, appunti delle lezioni del chiarissimo prof. Giovanni Pacchioni, (Milano, 1907); Legislazione comparata. Anno accademico 1907-1908, lezioni del chiarissimo prof. Giovanni Pacchioni (Pavia: Premiato stabilimento tipo-litografico succ. Bruni, [1908]); Legislazione comparata: anno accademico 1908-1909, lezioni tenute dal chiarissimo prof. Giovanni Pacchioni (Pavia: Premiato stabilimento tipo-litografico succ. Bruni, [1909]).

${ }^{36}$ Furio Ferraresi, "Mosca, Gaetano," in Dizionario Biografico degli Italiani 77 (2012); Pierpaolo Portinaro, "Mosca, Gaetano," in Il contributo italiano alla storia del Pensiero - Filosofia (Roma: Istituto della Enciclopedia Italiana, 2012); Claudio Martinelli, "Mosca, Gaetano," in Il contributo italiano alla storia del Pensiero - Storia e Politica (Roma: Istituto della Enciclopedia Italiana, 2013).

${ }^{37}$ Among other studies, in English see Studies on the political thought of Gaetano Mosca: the theory of the ruling class and its development abroad, ed. Ettore A. Albertoni (Milano: Giuffrè, 1982).

${ }^{38}$ Sante Violante, "L'economia e la politica come scienze. Itinerario ventennale di uno studioso: Gaetano Mosca, docente bocconiano," Giornale degli Economisti e Annali di Economia Nuova Serie 40/1/2 (1981): 51-64; Robertino Ghiringhelli, "Per una lezione critica delle lezioni di scienza politica di Gaetano Mosca all'Università Bocconi (1918-1923)," in Governo e governabilità nel sistema politico e giuridico di Gaetano Mosca, ed. Ettore A. Albertoni (Milano: 
In his teachings of constitutional law he developed a historical and comparative study of the British and American constitutions, as well as of other continental Europe constitutional experiences and finally he explained the Italian constitutional chart of those times, the Statuto Albertino. He also insisted on the political thought of the most important authors of the Enlightenment, such as Montesquieu and Rousseau. In his classes of political science he concentrated on single authors' doctrines. ${ }^{39}$

Mosca experimented with his theories through his teachings, from constitutional law to a comprehensive political and legal doctrine and towards his theory "of the ruling class" and a history of the political doctrines. Certainly, he could benefit from the courses he held at Bocconi, in a favourable environment for interdisciplinary studies among law, economics and social sciences. ${ }^{40}$

In synthesis, the comparative perspective adopted by jurists - and especially by law professors in their classes - was determined by a more general rethinking of the role of the jurists. The comparative approach was used differently in each teaching and it led to different outputs, such as the introduction of regular classes of comparative law and the development of new academic disciplines. ${ }^{41}$

Generally speaking, however, in Italian as well as in other European universities the introduction of comparative law classes was not the only renewal in law programs: in fact, at the turn of the $20^{\text {th }}$ century, new subjects such as industrial and labour law could not be ignored, ${ }^{42}$ while European universities

Giuffrè, 1983), 54-77. See also Alberto Martinelli, "Teoria politica e giornalismo. La collaborazione di Gaetano Mosca con il «Corriere della Sera»," in Gaetano Mosca e il «Corriere della Sera» 1897-1925, ed. Alberto Martinelli (Milano: Fondazione Coriere della Sera, 2013), IX-LVII.

${ }^{39}$ Among other students' notes, Gaetano Mosca, Corso di diritto costituzionale nel primo anno di fondazione dell'Università 1902-1903 (Milano: s.n., 1903); Diritto costituzionale, prof. G. Mosca, appunti raccolti da Vittorino Ricevuto (Milano: s.n., 1904); Diritto costituzionale: 1. corso, prof. G. Mosca, lezioni raccolte da Magnaghi (Milano: s.n., 1905); Diritto costituzionale e amministrativo: 1. corso. Anno accademico 1905-1906, prof. G. Mosca (Milano: s.n., 1906). See also Lezioni di scienza politica tenute dal chiarissimo on. prof. sen. G. Mosca, raccolte da Ugo Caprara, (Milano: Lit. Capra, 1920).

${ }^{40}$ Enrico De Mas, L'Italia tra ottocento e novecento e le origini della scienza politica (Mosca, Michels, Ferrero, Rensi) (Lecce: Miella, 1981); Francesco Mancuso, Gaetano Mosca e la tradizione del costituzionalismo (Napoli: ESI, 1999).

${ }^{41}$ Refer to Qu'est-ce qu'une discipline juridique? Fondation et recomposition des disciplines dans les facultés de droit, eds. Frédéric Audren and Ségolène Barbou des Places (Paris: LGDJ, forthcoming).

${ }^{42}$ For example, Annamaria Monti, "La concorrenza sleale e gli esordi del diritto industriale nell'Italia liberale: verso una teoria generale della concorrenza?," in " Afferrare 
also introduced new classes of sociology, ${ }^{43}$ political economy ${ }^{44}$ and statistics. ${ }^{45}$ And they did this very often apart from the general ordinary classes.

\section{Concluding remarks}

As I mentioned above, Italian late $19^{\text {th }}$ century academic law teaching was influenced by the German legal thought. Legal science 'prevailed' somehow on legal practice in sense that even practical teachings were 'transformed' in scientific disciplines. ${ }^{46}$

However, in their classes, Italian law professors had to deal with new national codes - the civil code "Pisanelli" of 1865 and the commercial code "Mancini" of 1882, above all - which were regarded as a fundamental step towards a real unification of the country. It will be very interesting to verify how they taught their students practical topics in a theoretical and scientific frame.

By examining the teaching of law, it is possible to evaluate the state of teaching methodologies at the time and their relationship with the legal doctrine and practice. In addition, it provides an opportunity to assess the extent to which university lectures were coming to grips with the profound social and economic changes of the era.

Concerning the sources, this can be verified through the analysis of the unofficial dispense, the notes collected in class by the most diligent students which were later lithographed and distributed among the others. ${ }^{47}$

...l'inafferrabile ». I giuristi e il diritto della nuova economia industriale fra Otto e Novecento, eds. Alberto Sciumé and Elisabetta Fusar Poli (Milano: Giuffrè, 2013), 130-134. Concerning Spain, see María José María e Izquierdo, "Las primeras cátedras de derecho laboral en la Universidad española," Cuadernos del Instituto Antonio de Nebrija 10 (2007): 251-267.

${ }^{43}$ Frédéric Audren, "Les professeurs de droit, la République et le nouvel esprit juridique. Introduction," La Belle Epoque des juristes. Enseigner le droit dans la République, Mil neuf cent, Revue d'histoire intellectuelle 29 (2011): 7-33.

${ }^{44}$ See Milano e la cultura economica nel XX secolo, I, Gli anni 1890-1920, ed. Pier Luigi Porta (Milano: Franco Angeli, [1998]).

${ }^{45}$ Giovanni Favero, "La statistica nell'università italiana: manuali e libri di testo dal 1848 al 1922," Il pensiero economico italiano 14 (2006): 143-173; Giovanni Favero, Ugo Trivellato, "La Statistica nell'Università di Padova: un percorso emblematico dalla restaurazione all'età repubblicana," Rivista di Storia economica 27 (2011): 21-60; Giovanni Favero, "La statistica nell'università italiana tra le due guerre," in La cultura economica tra le due guerre, eds. Piero Barucci, Simone Misiani and Manuela Mosca (Milano: Franco Angeli, 2015), 339-347.

${ }^{46}$ Massimo Severo Giannini, "Profili storici della scienza del diritto amministrativo [1940]," Quaderni fiorentini 2 (1973): 182-183.

${ }^{47}$ Giorgio Chiosso, "Stampatori ed editori per l'Università e la scuola tra Otto e primo No- 
While these lecture notes were study material that reflected what was taught in lectures, they did not always bear the approval of the professor himself. Indeed, they often had a bad reputation in the academic world, especially when the professor had not re-read and approved them, and this is something to keep in mind when examining them. Nonetheless, these notes today represent a precious tool for researchers, together with the official textbooks published by the professors themselves, to have in-depth access to the teaching methodology of the time. ${ }^{48}$

In many countries legal education was conceived in those times as a matter for Universities and cultural exchanges among professors coming from different countries were especially intensive in the new fields of study.

To this purpose, I believe the research project has to have a comparative perspective: legal thought circulated thorough different meanings, translations, conferences, personal correspondences and above all through law journals. ${ }^{49}$ My idea is that legal thought also circulated through law teaching. ${ }^{50}$ Not only, for example, did an Italian professor speak of French and German professors' doctrines to his students, but this same Italian professor was occasionally invited to teach at a foreign University.

As an example of possible developments from a comparative point of view, I mentioned the teachings of comparative law. They were held in Italy as well as in other countries and they were connected very frequently to the renewal of the legal thinking at the turn of the $20^{\text {th }}$ century. In addition, comparative law doctrines circulated among scholars of different countries in those years and the scholars themselves, not only their written works, trav-

vecento," in Dalla pecia all'e-book. Libri per l'Università: stampa, editoria, circolazione e lettura, eds. Gian Paolo Brizzi and Maria Gioia Tavoni (Bologna: CLUEB, 2009), 648-653.

${ }^{48}$ The lecture notes covered the exam programmes and this is very interesting, bearing in mind that "Examinations also influence the structure of academic knowledge and the history of disciplines" as stated by Robert Anderson, "Examinations and university models in nineteenth century Britain," Annali di Storia delle Università italiane 19/1 (2015): 103.

${ }^{49}$ See for example the review of Mario Sarfatti's work by Sheldon Amos, "An Italian view of the Law of Torts," Journal of Comparative Legislation (1903): 274-278. From a methodological point of view, see Eduardo Zimmermann, "Translations of the 'American Model' in Nineteenth Century Argentina: Constitutional Culture as a Global Legal Entanglement," in Entanglements in Legal History. Conceptual Approaches, ed. Thomas Duve (Frankfurt am Main: Max Planck Institute for European Legal History, 2014), 385-425.

${ }^{50}$ See Transnational intellectual networks : forms of academic knowledge and the search for cultural identities, eds. Christophen Charle, Jürgen Schriewer, Peter Wagner (Frankfurt - New York: Campus Verlag, 2004). 
elled: ${ }^{51}$ Mario Sarfatti, for example, went regularly to Lyon, where Edouard Lambert invited him to teach seminars on English law. ${ }^{52}$

In synthesis, between the end of the 19th century and World War One, new courses and teaching methods were introduced, which in turn gave rise to new scientific disciplines that would be further developed over the course of the 20th century. ${ }^{53}$ And these same disciplines we are now trying to overcome were often born through transnational exchanges. In fact, I believe that a comparative perspective is essential to grasp not only single national situations, but also - and most important - the general transnational evolution of law teaching methods which occurred back then.

\section{Bibliography}

Albertoni, Ettore A. ed. Studies on the political thought of Gaetano Mosca: the theory of the ruling class and its development abroad. Milano: Giuffrè, 1982.

Alvazzi del Frate, Paolo and Dario Di Cecca. "Droit et méthodologie. Les prolusioni accademiche en Italia au XIXe siècle." Revue d'histoire des Facultés de droit et de la culture juridique 31 (2011): 117-38.

Amos, Sheldon. "An Italian view of the Law of Torts." Journal of Comparative Legislation (1903): 274-278.

ANDERSON, ROBERT D. European Universities from Enlightenment to 1914. Oxford: Oxford University Press, 2004.

ANDERSON, RoBERT. "Examinations and university models in nineteenth century Britain," Annali di Storia delle Università italiane 19/1 (2015): 103-23. AUDREN, FRÉDÉRIC and JEAN-LOUIS HALPÉRIN. La culture juridique française. Entre mythes et réalités. Paris: CNRS Editions, 2013.

${ }^{51}$ This process of intellectuals' circulation and teaching innovations had a wide dimension: for the US experience, refer to D. M. Rabban, Law's History.

${ }^{52}$ According to the documents kept in Archivio storico dell'Università di Torino, Fascicolo personale di Mario Sarfatti. See also Carlos Petit, "Harvard en Lyon. Lecturas de Roscoe Pound en el Institut de Lambert," in Excerptiones Iuris. Studies in Honor of André Gouron, eds. Bernard Durand, Laurent Mayali (Berkeley: Robbins Collection, 2000), 503-554.

${ }^{53}$ See Manuel Ángel Bermejo Castrillo, "Hacia la construcción de una ciencia procesal como disciplina universitaria autónoma: primeras cátedras, vigencia de la práctica y hegemonía del procedimento," Cuadernos del Instituto Antonio de Nebrija 4 (2001): 91-133; Manuel Ángel Bermejo Castrillo, "En los orígenes de la ciencia procesal española. Francisco Beceña: trayectoria académica, inquietudes docentes y aportación doctrinal," Cuadernos del Instituto Antonio de Nebrija 11/2 (2008): 143-211. 
Audren, FrédÉRIC and SÉGolÈne Barbou des Places eds. Qu'est-ce qu'une discipline juridique? Fondation et recomposition des disciplines dans les facultés de droit. Paris: LGDJ, forthcoming 2016.

AUdREN, FrÉDÉRIC. “Conclusion. Les juristes en travailleurs manuels." In Histoire des manuels de droit. Une histoire de la littérature juridique comme forme du discours universitaire, edited by Anne-Sophie Chambost, 337345. Paris: LGDJ, 2014.

AudREN, FrÉDÉRIC. "Les professeurs de droit, la République et le nouvel esprit juridique. Introduction." La Belle Epoque des juristes. Enseigner le droit dans la République, Mil neuf cent, Revue d'histoire intellectuelle 29 (2011): 7-33.

Bagiotti, Tullio. Storia della Università Bocconi 1902-1952. Milano: Università Bocconi, 1952.

Bermejo CAstrillo, Manuel Ángel. "En los orígenes de la ciencia procesal española. Francisco Beceña: trayectoria académica, inquietudes docentes y aportación doctrinal." Cuadernos del Instituto Antonio de $\mathrm{Ne}$ brija 11/2 (2008): 143-211.

Bermejo Castrillo, Manuel Ángel. "Hacia la construcción de una ciencia procesal como disciplina universitaria autónoma: primeras cátedras, vigencia de la práctica y hegemonía del procedimento." Cuadernos del Instituto Antonio de Nebrija 4 (2001): 91-133.

CAPogrossi Colognesi, Luigi. Modelli di stato e di famiglia nella storiografia dell'800. Roma: La Sapienza, 1994.

Caravale, Mario. "«Come si assicurano i diritti degli individui e delle nazioni? Colla libertà costituzionale» I primi corsi di diritto costituzionale a Roma dopo l'Unità." In Retoriche dei giuristi e costruzione dell'identità nazionale, edited by Giovanni Cazzetta, 203-30. Bologna: Il Mulino, 2013.

CARAVAle, Mario. "Introduzione." In La Facoltà giuridica romana in età liberale. Prolusioni e discorsi inaugurali, edited by Mario Caravale and Francesca Laura Sigismondi, XIII-XXII. Napoli: Jovene, 2014.

Cattini, Marco, Enrico Decleva, Aldo De Maddalena and Marzio Achille RomAnI, Storia di una libera università, I, L'Università Commerciale Luigi Bocconi dalle origini al 1914. Milano: Giuffrè, 1992.

CAZzetTA, GiovanNi. "Prolusioni, prelazioni, discorsi. L'identità nazionale nella retorica dei giuristi." In Retoriche dei giuristi e costruzione dell'identità nazionale, edited by Giovanni Cazzetta, 11-29. Bologna: Il Mulino, 2013.

Charle, Christophen, JÜrgen SchrieWer, Peter WAgner ed. Transnational intellectual networks : forms of academic knowledge and the search for cultural identities. Frankfurt - New York: Campus Verlag, 2004. 
Chiosso, Giorgio. "Stampatori ed editori per l'Università e la scuola tra Otto e primo Novecento." In Dalla pecia all'e-book. Libri per l'Università: stampa, editoria, circolazione e lettura, edited by Gian Paolo Brizzi and Maria Gioia Tavoni, 648-653. Bologna: CLUEB, 2009.

Cianferotti, GiUlio. “Germanesimo e università in Italia alla fine dell'800. Il caso di Camerino." Studi senesi (1988): 327-47.

Cianferotti, Giulio. "L'università di Siena e la 'vertenza Scialoja'. Concettualismo giuridico, giurisprudenza pratica e insegnamento del diritto in Italia alla fine dell'Ottocento." Studi Senesi Supplemento II (1988): 725-50.

CiAnFERotTi, Giulio. "La prolusione di Orlando. Il paradigma pandettistico, i nuovi giuristi universitari e lo Stato liberale." Rivista trimestrale di diritto pubblico 4 (1989): 995-1023.

Colao, Floriana. La libertà di insegnamento e l'autonomia nell'Università liberale. Norme e progetti per l'istruzione superiore in Italia. Milano: Giuffrè, 1995.

DE MAS, EnRICo. L'Italia tra ottocento e novecento e le origini della scienza politica (Mosca, Michels, Ferrero, Rensi). Lecce: Miella, 1981.

Di Renzo Villata, Maria Gigliola. "Per una storia del diritto (italiano). Antonio Pertile e la prima cattedra della materia." Quaderni per la storia dell'Università di Padova 45 (2012): 63-103.

"Diccionario de catédraticos españoles de derecho." Accessed May 13, 2016. http://portal.uc3m.es/portal/page/portal/instituto_figuerola/programas/phu/diccionariodecatedraticos.

Favero, Giovanni and Ugo Trivellato, "La Statistica nell'Università di Padova: un percorso emblematico dalla restaurazione all'età repubblicana." Rivista di Storia economica 27 (2011): 21-60.

FAVERo, Giovanni. "La statistica nell'università italiana tra le due guerre." In La cultura economica tra le due guerre, edited by Piero Barucci, Simone Misiani and Manuela Mosca, 339-347. Milano: Franco Angeli, 2015.

FAVERo, GiovanNI. "La statistica nell'università italiana: manuali e libri di testo dal 1848 al 1922." Il pensiero economico italiano 14 (2006): 143173.

FERRARESI, FurIo. "Mosca, Gaetano." In Dizionario Biografico degli Italiani 77 (Roma: Istituto della Enciclopedia Italiana, 2012), accessed May 15, 2016, http://www.treccani.it/enciclopedia/gaetano-mosca_(Dizionario-Biografico)/

FERRI, GIORDANo, "Studi di diritto processuale civile nella Facoltà giuridica romana tra Ottocento e Novecento." Historia et ius 4 (2013), paper 9. 
FIORI, Antonia. "Gli insegnamenti storico-giuridici alla Sapienza negli ultimi decenni del XIX secolo." Historia et ius 4 (2013), paper 10.

Fisch, STEFAN. Geschichte der europäischen Universität. Von Bologna nach Bologna. München: C.H. Beck, 2015.

GARRÉ, RoY. "Prospettive della comparazione giuridica nel pensiero e nell'opera di J.J. Bachofen (1815-1887)." In La comparazione giuridica tra Ottocento e Novecento. In memoria di Mario Rotondi, 99-120. Milano: Istituto Lombardo di Scienze e Lettere, 2001.

GHIRINGHelli, Robertino. "Per una lezione critica delle lezioni di scienza politica di Gaetano Mosca all'Università Bocconi (1918-1923).” In Governo e governabilità nel sistema politico e giuridico di Gaetano Mosca, edited by Ettore A. Albertoni, 54-77. Milano: Giuffrè, 1983.

Giannini, Massimo Severo. "Profili storici della scienza del diritto amministrativo [1940].” Quaderni fiorentini 2 (1973): 182-183.

Grossi, Paolo, Scienza giuridica italiana. Un profilo storico. Milano: Giuffrè, 2002.

Grossi, PAOLO. "Le 'prolusioni' dei civilisti e la loro valenza progettuale nella storia della cultura giuridica italiana." Quaderni fiorentini 41 (2012): 399-426.

Grossi, PAOLO. « La scienza del diritto privato ». Una rivista-progetto nella Firenze di fine secolo. 1893-1896. Milano: Giuffrè, 1988.

HALPÉRIN, JEAn-Louis. Histoire de l'état des juristes. Allemagne, XIXe-XXe siècles Paris: Classiques Garnier, 2015.

"I professori dell'Università di Pavia (1859-1961)". Accessed May 13, 2016. http://prosopografia.unipv.it/.

Jouanjan, Olivier, and Elisabeth Zoller eds. Le "moment 1900". Critique sociale et critique sociologique du droit en Europe et aux Etats-Unis. Paris: Editions Panthéon Assas, 2015.

JoUANJAN, OLIVIER. Une histoire de la pensée juridique en Allemagne (18001918). Idéalisme et conceptualisme chez les juristes allemands du XIXe siècle. Paris: PUF, 2005.

"La Scuola di Torino. Da Cognetti de Martiis a Einaudi," Il pensiero economico italiano XII/2 (2004).

Mancuso, Francesco. Gaetano Mosca e la tradizione del costituzionalismo. Napoli: ESI, 1999.

Marchionatti, Roberto, Francesco Cassata, Giandomenica Becchio and FIorenzo MoRnATI. "«Quando l'economia italiana non era seconda a nessuno ». Luigi Einaudi e la Scuola di economia di Torino." In Luigi Einaudi nella cultura, nella società e nella politica del Novecento, edited 
by Roberto Marchionatti, Paolo Soddu, 57-99. Firenze: L. S. Olschki, 2010.

MARÍA E IZQUiERdo, MARÍA JosÉ. "Las primeras cátedras de derecho laboral en la Universidad española." Cuadernos del Instituto Antonio de Nebrija 10 (2007): 251-267.

MARTín, Sebastián. "De la enseñanza a la ciencia del derecho: biografía colectiva de juristas españoles (1857-1943)." Cuadernos del Instituto Antonio de Nebrija 12/1 (2009): 33-51.

Martinelli, AlBerto. "Teoria politica e giornalismo. La collaborazione di Gaetano Mosca con il «Corriere della Sera»." In Gaetano Mosca e il «Corriere della Sera» 1897-1925, ed. Alberto Martinelli, IX-LVII. Milano: Fondazione Coriere della Sera, 2013.

Martinelli, Claudio. "Mosca, Gaetano," in Il contributo italiano alla storia del Pensiero - Storia e Politica (Roma: Istituto della Enciclopedia Italiana, 2013), accessed May 15, 2016, http://www.treccani.it/enciclopedia/gaetano-mosca_(altro)/

Martínez Neira, Manuel. "Los libros útiles o la utilidad de los libros. Manuales de derecho entre 1841 y 1845." In Manuales y textos de enseñanza en la Universidad liberal, edited by Manuel Ángel Bermejo Castrillo, 581-92. Madrid: Instituto Antonio de Nebrija de estudios sobre la Universidad, 2004.

Martínez NeIRA, Manuel. El estudio del derecho libros de texto y planes de estudio en la universidad contemporánea. Madrid: Instituto Antonio de Nebrija de estudios sobre la Universidad, 2001.

Mattone, Antonello. "Gli studi giuridici e l'insegnamento del diritto (XVIIXX secolo)." In Storia dell'Università di Sassari, edited by Antonello Mattone, 205-35. Nuoro: Ilisso, 2010.

MazzaCANe, ALdo AND CRISTINA VANo. Università e professioni giuridiche in Europa nell'età liberale. Napoli: Jovene, 1994.

MazzaCANE, Aldo ed. I giuristi e la crisi dello Stato liberale in Italia fra Otto e Novecento. Napoli: Liguori Editore, 1986.

MazzACAnE, Aldo ed. L'esperienza giuridica di Emanuele Gianturco. Napoli: Liguori Editore, 1987.

MazzaCANE, ALDo. "Secolo dell'università - secolo delle professioni: le ragioni di un incontro." In Università e professioni giuridiche in Europa nell'età liberale, 3-9. Napoli: Jovene, 1994.

Mazzarella, Ferdinando. "Darwinismo, storicismo, socialità. «La nuova tendenza» di Giuseppe Vadalà-Papale" Quaderni fiorentini 41 (2012): 583-626. 
Mazzarella, Ferdinando. "Dialoghi a distanza in tema di socialità e storicità del diritto. Italia, Francia e Germania tra fine Ottocento e primo Novecento." Quaderni fiorentini 44/1 (2015): 381-424.

Monti, AnNAMARIA. "Alla scoperta del diritto anglo sassone: il contributo di Mario Sarfatti (1876 - 1962) alla comparazione giuridica." In Lavorando al cantiere del "Dizionario biografico dei giuristi italiani (XII-XX sec.)", edited by Maria Gigliola di Renzo Villata, 589-623. Milano: Giuffrè, 2013.

MonTI, AnNAmARIA. "Enseigner le droit en Italie au début du XXe siècle: les cours de législation comparée de Giovanni Pacchioni (1867-1946)." In Aux confins du droit. Mélanges-Hommage amical à Xavier Martin, 305314. Paris: LGDJ, 2015.

MonTI, ANNAMARIA. "La concorrenza sleale e gli esordi del diritto industriale nell'Italia liberale: verso una teoria generale della concorrenza?" In " Afferrare ...l'inafferrabile ». I giuristi e il diritto della nuova economia industriale fra Otto e Novecento, edited by Alberto Sciumé and Elisabetta Fusar Poli, 109-41. Milano: Giuffrè, 2013.

MonTI, ANNAMARIA. "Tradizione e rinnovamento nella didattica giuridica: prime riflessioni per un'indagine sull'Italia liberale." Rivista di storia del diritto italiano 87 (2014): 287-312.

MoRETTI, MASSIMO and ILARIA PORCIANI. "Il reclutamento accademico in Italia. Uno sguardo retrospettivo." Annali di storia delle università italiane (1997): 11-39.

Mosca, GaEtano. Corso di diritto costituzionale nel primo anno di fondazione dell'Università 1902-1903. Milano, 1903.

Mosca, Gaetano. Diritto costituzionale e amministrativo: 1. corso. Anno accademico 1905-1906. Milano, 1906.

Mosca, Gaetano. Diritto costituzionale, appunti raccolti da Vittorino Ricevuto. Milano, 1904.

Mosca, Gaetano. Diritto costituzionale: 1. corso lezioni raccolte da Magnaghi. Milano, 1905.

Mosca, Gaetano. Lezioni di scienza politica tenute dal chiarissimo on. prof. sen. G. Mosca, raccolte da Ugo Caprara. Milano: Lit. Capra, 1920.

MusIEDLAK, DidIER. Université privée et formation de la classe dirigeante: l'exemple de l'Université L. Bocconi de Milan (1902-1925). Roma: Ecole française de Rome, 1990.

Musselli, LuCiano. "La Facoltà di Giurisprudenza di Pavia nel primo secolo dell'Italia unita (1860-1960)." Annali di Storia delle Università italiane 7 (2003). http://www.cisui.unibo.it/frame_annali.htm. 
NARDI, PAOlo. "Lodovico Zdekauer a Macerata tra archivi e insegnamento universitario." Annali di Storia delle Università italiane 14 (2010). http://www.cisui.unibo.it/frame_annali.htm.

NEgRI, ALBA. Il giurista dell'area romanista di fronte all'etnologia giuridica. Milano: Giuffrè, 1983.

ORESTANO, RicCARDo. Introduzione allo studio del diritto romano. Bologna: Il Mulino, 1987.

Pacchioni, Giovanni. Corso speciale di legislazione comparata. Anno accademico 1906-1907. Milano, 1907.

Pacchioni, Giovanni. Legislazione comparata. Anno accademico 1907-1908. Pavia: Premiato stabilimento tipo-litografico succ. Bruni, [1908].

Pacchioni, GiovanNi. Legislazione comparata: anno accademico 1908-1909. Pavia: Premiato stabilimento tipo-litografico succ. Bruni, [1909].

Pace Gravina, Giacomo ed. La Facoltà di Giurisprudenza della Regia Università degli Studi di Messina (1908-1946). Messina: GBM, 2009.

PASSERO, LAURA. "La Facoltà giuridica pisana negli anni Ottanta dell'Ottocento." Studi Senesi (2007): 322-59.

Petit, Carlos. "«Qualcosa che somiglia all'ammirazione». Ecos de la Civilística italiana en España." In Giuseppe Pisanelli. Scienza del processo cultura delle leggi e avvocatura tra periferia e nazione, edited by Cristina Vano, 397-444. Napoli: Jovene, 2005.

Petit, CARlos. "De la historia a la memoria. A propósito de una reciente obra de historia universitaria." Cuadernos del Instituto Antonio de Nebrija 8 (2005): 237-279.

Petit, CARlos. "Harvard en Lyon. Lecturas de Roscoe Pound en el Institut de Lambert." In Excerptiones Iuris. Studies in Honor of André Gouron, edited by Bernard Durand, Laurent Mayali, 503-554. Berkeley: Robbins Collection, 2000.

Petit, CARlos. "Lambert en la Tour Eiffel, o el derecho comparado de la Belle Epoque." In La comparazione giuridica tra Ottocento e Novecento. In memoria di Mario Rotondi, 53-98. Milano: Istituto Lombardo di Scienze e Lettere, 2001.

Porciani, ILARIA and MAURo MoretTI. "La creazione del sistema universitario nella nuova Italia." In Storia delle Università in Italia, edited by Gian Paolo Brizzi, Piero Del Negro and Andrea Romano, I, 323-79. Messina: Sicania, 2007.

PoRCIANI, ILARIA ed. L'università tra Otto e Novecento: i modelli europei e il caso italiano. Napoli: Jovene, 1994. 
Porta, PIER Luigi ed. Milano e la cultura economica nel XX secolo, I, Gli anni 1890-1920. Milano: Franco Angeli, [1998].

Portinaro, Pierpaolo. "Mosca, Gaetano." In Il contributo italiano alla storia del Pensiero - Filosofia (Roma: Istituto della Enciclopedia Italiana, 2012), accessed May 15, 2016, http://www.treccani.it/enciclopedia/ gaetano-mosca_(Il_Contributo_italiano_alla_storia_del_Pensiero:_Filosofia)/

Post, Alberto Ermanno. Giurisprudenza etnologica, traduzione con prefazione e postille dei professori Pietro Bonfante e Carlo Longo dell'Università di Pavia, vol. I. Milano: Società editrice libraria, 1906.

PuCCINI, SANDRA. "A casa e fuori: antropologi, etnologi, viaggiatori." In Scienza e cultura dell'Italia unita, Storia d'Italia, Annali, 26, edited by Francesco Cassata and Claudio Pogliano, 547-573. Torino: Einaudi, 2011.

RabBan, David M. Law's History. American legal Thought and the Transatlantic Turn to History. New York, Cambridge University Press, 2013.

Richard, Guillaume. "La Faculté de Paris et l'aide aux étudiants sous la Troisième République." In Paris, capital juridique (1804-1950). Etude de socio-histoire sur la Faculté de droit de Paris, edited by Jean-Louis Halpérin, 205-19. Paris: Editions Rue d'Ulm, 2011.

Richard, Guillaume. Enseigner le droit public à Paris sous la Troisième République. Paris: Dalloz, 2015.

RomANI, MARzio ACHILLE. "I problemi e le riforme didattiche nella prima «università commerciale» italiana: la Bocconi (1902-1932)." Annali di Storia delle Università italiane 19 (2015): 125-135.

RÜCKERT, JOACHIM, and RALF SEINECKE eds. Methodik des Zivilrechts: von Savigny bis Teubner. Baden-Baden: Nomos Verlagsgesellschaft, 2012.

RÜCKERT, JOACHIM, and Thomas Duve eds. Savigny International? Frankfurt am Main: Vittorio Klostermann, 2015.

SARFATTI, MARIO. "Sull'utilità dello studio del diritto privato inglese in Italia. Prolusione al corso libero di diritto civile comparato, R. Università di Torino 15 dicembre 1906." Il Filangieri 32 (1907).

SARFATTI, MARIO. Introduzione allo studio del diritto comparato. Torino: Giappichelli, 1933.

SCHIAVONE, ALDO. "Un'identità perduta: la parabola del diritto romano in Italia." In Stato e cultura giuridica in Italia dall'Unità alla Repubblica, edited by Aldo Schiavone, 275-302. Roma - Bari: Laterza, 1990.

SPAGNESI, EnRICo. "L'insegnamento del diritto 'al modo pisano' (1861-1945)." Annali di Storia delle Università italiane 14 (2010). http://www.cisui. unibo.it/frame_annali.htm. 
Stolleis, Michael. A history of public law in Germany, 1914-1945, translated by Thomas Dunlap. Oxford - New York: Oxford University Press, 2004. "Système d'information des professeurs de droit (1804-1950)." Accessed May 13, 2016. http://siprojuris.symogih.org/.

TOMASI, TINA and LUCiANA BELlatalla, L'Università italiana nell'Italia liberale (1861-1923). Napoli: Liguori Editore, 1988.

Treggiari, Ferdinando. "Itinerari della casistica. La crestomazia di Emanuele Gianturco fra modelli illustri e nuove istanze." In Emanuele Gianturco, Crestomazia di casi giuridici in uso accademico, V-XLVI. Rist. an. Bologna: Forni, 1989.

VIOLANTE, SANTE. "L'economia e la politica come scienze. Itinerario ventennale di uno studioso: Gaetano Mosca, docente bocconiano." Giornale degli Economisti e Annali di Economia Nuova Serie 40/1/2 (1981): 51-64.

WIEACKER, FRANZ. A history of private law in Europe: with particular reference to Germany, translated by Tony Weir, foreword by Reinhard Zimmermann. Oxford: Clarendon Press, 1998.

ZimmermanN, EdUARDo. “Translations of the 'American Model' in Nineteenth Century Argentina: Constitutional Culture as a Global Legal Entanglement." In Entanglements in Legal History. Conceptual Approaches, edited by Thomas Duve, 385-425. Frankfurt am Main: Max Planck Institute for European Legal History, 2014. 